\title{
PENDIDIKAN REMAJA UNTUK MENYONGSONG MASA DEPAN BANGSA \\ Syamsudin
}

Sekolah Tinggi Agama Islam (STAINU) Pacitan

\begin{abstract}
Abstrak: Remaja adalah masyarakat yang akan datang. Dapat di perkirakan bahwa gambaran kaum remaja sekarang adalah pencerminan masyarakat yang akan dating. Namun kenyataan telah menunjukkan bahwa perubahan zaman yang ditamdai dengan kemajuan ilmu pengetahuan dan tehnologi selalu mengakibatkan perubahan sosial. Hal ini tidak dapat di sepelekan karena remaja adalah subuah miniatur masa depan Bangsa. Dari moral, pekerti dan karyanya yang akan membawa Negara lebih maju dan bersaing di dalam kerasnya masa globalisasi saat ini.
\end{abstract}

\section{PENDAHULUAN}

Wacana nasionalisme dalam kehidupan berbangsa dan bernegara di era globalisasi ini memiliki daya tarik karena sekarang kobaran semangat nasionalisme generasi muda mulai luntur. Lunturnya nasionalisme bangsa dapat menjadi kecaman terhadap terkikisnya nilainilai patriotism yang menjadi landasan kecintaan terhadap bumi pertiwi.

Munculnya tuntutan-tuntutan seperti untuk membangun bangsa yang demokratis, sejahtera, adil, dan makmur semakin mengemuka dikalangan masyarakat luas. Itulah sebabnya, nasionalisme menjadi kunci utama dalam merealisasikan cita-cita luhur bangsa Indonesia untuk menjadi bangsa yang disegani dan berdaulat secara utuh. Upaya menumbuhkan semangat nasionalisme generasi muda, pemerintah memiliki peran penting dalam memberikan pemahaman dan motivasi kepada semua anak bangsa agar jiwa nasionalisme dan rasa cinta mereka terhadap bangsanya (patriotisme) semakin kuat dan tertanam dalam sanubari mereka yang paling dalam. Upaya yang dilakukan pemerintah salah satunya melalui pendidikan.

Pendidikan sebagai salah satu proses perubahan pada pembentuk sikap, kepribadian dan keterampilan manusia untuk menghadapi masa depan. Dalam proses pertumbuhan dan perkembangan itu dipengaruhi oleh berbagai faktor yang menyangkut perilaku manusia, kemampuan dan kemauan belajar sehingga pada akhirnya proses mendorong pertumbuhan dan perkembangan ke arah satu tujuan yang dicita-citakan dan diharapkan perubahan tersebut membawa dampak positif.

Oleh karena itu manusia harus memiki karakter karena manusia yang tidak memiliki karakter sama saja dengan binatang yang tidak tahu malu dan tidak memiliki akal 
seperti manusia. Maksudnya di sini sama seperti binatang yaitu sifat manusia yang tidak wajar lagi sudah sama seperti hewan yang tidak memikirkan apa pun.

Rasa nasionalisme yang semakin merosot terjadi karena banyak generasi muda tidak mengerti tentang sulitnya merebut kemerdekaan dari penjajah. Ini yang membuat generasi muda hampir tidak memiliki rasa nasionalisme. seolah acuh tak acuh akan perjuangan pahlawan dengan tidak memahami hakikat bangsanya sendiri. Salah satu generasi penerus yang berbangsa dan bernegara harus mencintai bangsa dan negaranya sendiri. Sebagai warga negara yang baik tak seharusnya memiliki alasan untuk tidak mencintai bangsanya, dan harus bangga menjadi bagian dari bangsa Indonesia merupakan salah satu contoh ringan dalam upaya bela negara.

Cinta tanah air atau bela negara adalah suatu sikap yang harus dimiliki warga negara Indonesia, terutama siswa pada jenjang sekolah menegah. karena siswa-siswi yang akan menjadi generasi penerus bangsa harus memiliki rasa cinta tanah air, kesadaran berbangsa dan bernegara Indonesia. Karena sebagai bangsa Indonesia harus bisa mencintai dan membela negaranya sendiri. Berkeyakinan kepada dasar negara yaitu Pancasila sebagai ideologi negara dan kerelaan untuk berkorban guna meniadakan setiap ancaman baik dari luar maupun dalam negeri yang membahayakan keutuhan NKRI.

Internalisasi nilai-nilai nasionalisme merupakan sebagian kecil dari rencana pendidikan yang ada. Jadi internalisasi merupakan proses belajar kebudayaan yang ditanamkan dalam setiap individu. Melalui internalisasi nilai-nilai budaya yang terkandung dalam pendidikan dapat membentuk karakter bangsa dan mencegah negatifnya globalisasi dan menanamkan nasionalisme bangsa. Melalui pendidikan upaya internalisasi dapat berlangsung guna membentuk sikap dan karakter siswa (Muhaimin, 2004:209).

Berbicara mengenai remaja yang terutama berkaitan dengan masalah kenakalan adalah merupakan masalah yang dirasakan sangatlah penting dan menarik untuk dibahas karena seseorang yang namanya remaja yang merupakan bagian dari generasi muda adalah aset Nasional dan merupakan tumpuhan harapan bagi masa depan bangsa dan Negara serta agama. Untuk mewujudkan semuanya dan demi kejayaan bangsa dan Negara serta agama kita ini, maka sudah barang tentu menjadi kewajiban dan tugas kita semua baik orang tua, pendidik (guru) dan pemerintah untuk mempersiapkan generasi muda menjadi generasi yang tangguh dan berwawasan atau berpengetahuan yang luas dengan jalan membimbing dan menjadikan mereka semua sehingga menjadi warga Negara yang baik dan bertanggung jawab secara moral. Dengan proses penbimbingan dan mengarahkan generasi muda yang tangguh dan memiliki 
wawasan atau pengetahuan yang luas saja tidaklah cukup rasanya, akan tetapi semuanya haruslah di lengkapi dengan adanya penanaman jiwa keberagamaan yang tinggi. Dan berkaitan dengan hal ini maka Winarno Surakhmad mengatakan:

"Adalah suatu fakta di dalam sejarah pembangunan umat yang akan memelihara keberlangsungan hidupnya untuk senantiasa menyerahkan dan mempercayakan hidupnya di dalam tangan generasi yang lebih muda. Generasi muda itulah yang kemudian memikul tanggung jawab untuk tidak saja memelihara kelangsungan hidup umatnya tetapi juga meningkatkan harkat hidup tersebut. Apabila generasi muda yang seharusnya menerima tugas penulisan sejarah bangsanya tidak memiliki kesiapan dan kemampuan yang diperlukan oleh kehidupan bangsa itu, niscaya berlangsung kearah kegersangan menuju kepada kekerdilan dan akhirnya sampai pada kehancuran. Karna itu, kedudukan angkatan muda dalam suatu masyarakat adalah vital bagi masyarakat itu. ${ }^{1}$

Kalau kita lihat pendapat di atas mengandung arti bahwa tanggung jawab dari generasi muda (remaja) di masa yang akan datang sangatlah berat, yaitu mempertahankan kelangsungan hidup dan meningkatkan harkat hidup umat manusia. Untuk itu adanya upaya-upaya pendidikan dan pembinaan moral (akhlak) terhadap remaja sebagai generasi penerus suatu bangsa sangatlah wajar dan mutlak diperlukan dengan kepribadian yang memiliki budi pekerti dan akhlak yang mulia sebagai bekal hidup dimasa yang akan datang. Yang sudah pasti tantangan dan hambatan untuk membangun sebuah kemajuan atau peradapan baru lebih besar dari saat ini. Sebab apabila dari pribadi generasi muda telah memiliki budi pekerti dan akhlak yang mulia, maka keberlangsumgan hidup suatu bangsa akan dapat di pertahankan. Namun sebaliknya, apabila para remaja memiliki akhlak yang rendah atau rusak, maka akan terjadilah kerusakan terhadap keberlangsungan hidup bangsa itu.

Dewasa ini tuntutan akan pendidikan semakin meningkat. Hal ini merupakan dorongan yang sangat kuat untuk membangun ilmu pengetahuan dan tehnologi yang semakin maju untuk memenuhi kebutuhan hidup yang sedemikian rupa, maka tidak dapat di elakkan lagi kalau pendidikan memegang peran penting dalam menghadapi era yang moderen saat ini.

Remaja adalah masyarakat yang akan datang. Dapat di perkirakan bahwa gambaran kaum remaja sekarang adalah pencerminan masyarakat yang akan datang, baik buruknya bentuk dan susunan masyarakat, bangunan moral dan intelektual, dalam penghayatan terhadap agama, kesadaran kebangsaan, dan derajat kemajuan prilaku dan kepribadian antara sesama masyarakat yang akan datang tergantung kepada remaja sekarang. ${ }^{2}$

\footnotetext{
${ }^{1}$ Winarno Surakhmad, Psikologi Pemuda, Bandung, 1997, hal: 12-13

${ }^{2}$ Nurdin Samauna, Pengarug Globalisasi Terhadap Moral Remaja Sebagai Sumberdaya Manusia Dalam PJPT II, no,36/XII/oktober 1994, hal: 14
} 
Perwujudan dan sistem dan iklim pendidikan nasional yang demokratis dan bermutu guna memperteguh akhlak mulia, kreatif, inovatif, berwawasan kebangsaan, cerdas, sehat, berdisiplin dan bertanggung jawab, berketrampilan serta menguasai ilmu pengetahuan dan teknologi dalam rangka mengembangkan kualitas manusia Indonesia. ${ }^{3}$

Namun demikian, pendidikan yang berlansung selama ini masih dianggap kurang bermakna bagi pengembangan pribadi dan watak peserta didik. Hal ini dibuktikan dengan banyaknya kasus-kasus sosial kemasyarakatan, yang terjadi cenderung membahayakan kepentingan bersama dan kurang memiliki kepekaan yang cukup untuk membina toleransi dan keberagamaan dalam kondisi masyarakat yang kian majmuk dengan berbagai macam kepentingannya.

Namun kenyataan telah menunjukkan bahwa perubahan zaman yang ditandai dengan kemajuan ilmu pengetahuan dan teknologi selalu mengakibatkan perubahan sosial, dengan semakin canggihnya teknologi komonikasi, transportasi dan sistem informasi membuat perubahan masyarakat semakin melaju dengan cepat. Dalam menghadapi situasi yang demikian remaja sering kali memiliki jiwa yang lebih sensitif, yang pada akhirnya tidak sedikit para remaja yang terjerumus ke hal-hal yang bertentangan dengan nilai-nilai moral, norma agama, norma sosial serta norma hidup dimasyarakat oleh karena itu remaja akan cenderung mempunyai tingkah laku yang tidak wajar dalam arti melakukan tindakkan yang tidak pantas.

Dalam bukunnya "Kesehatan Mental" mengemukakan beberapa faktor yang menyebabkan timbulnya kenakalan remaja adalah sebagai berikut:

1. Kurang pendidikan

2. Kurang pengertian orang tua tentang pendidikan

3. Kurang teraturnya pengisian waktu

4. Tidak stabilnya keadaan sosial, politik dan ekonomi

5. Banyaknya film dan buku-buku bacaan yang tidak baik

6. Menyusutnya moral dan mental orang dewasa

7. Pendidikan dalam sekolah yang kurang baik

8. Kurangnya perhatian masyarakat dalam pendidikan anak. ${ }^{4}$

Beberapa faktor penyebab kenakalan remaja yang tampak dalam kutipan di atas dapat diamati bahwa faktor-faktor tersebut bersumber pada tiga keadaan yang terjadi dalam

\footnotetext{
${ }^{3}$ TAP MPR RI NO.IV/MPR/1999, tentang GBHN, Sinar Grafindo, Jakarta, 1999,2000, hal: 15

${ }^{4}$ Ibid,hlm: 113
} 
lingkungan keluarga, sekolah, dan masyarakat. Oleh karna itu upaya untuk mengatasinya merupakan tanggung jawab bersama antara orang tua, guru di sekolah dan masyarakat.

Kegiatan pendidikan di sekolah, sampai saat ini masih merupakan wahana sentral dalam mengatasi berbagai bentuk kenakalan remaja yang terjadi. Oleh karna itu segala apa yang terjadi dalam lingkungan di luar sekolah, senantiasa mengambil tolak ukur aktivitas pendidikan dan pembelajaran sekolah. Hal seperti ini cukup disadari oleh para guru dan pengelolah lembaga pendidikan, dan mereka melakukan berbagai upaya untuk mengantisipasi dan memaksimalkan kasus-kasus yang terjadi akibat kenakalan siswanya melalui penerapan tata tertib pembelajaran moral, agama dan norma-norma susila lainnya.

Mengingat betapa pentingnya peranan remaja sebagai generasi muda bagi masa depan bangsa. Maka dibawah ini akan kami deskripsikan tentang perkembangan karakter remaja.

\section{ISI}

\section{A. Pengertian Remaja}

Remaja adalah masyarakat yang akan datang. Dapat diperkirakan bahwa gambaran kaum remaja sekarang adalah pencerminan masyarakat yang akan datang, baik buruknya bentuk dan susunan masyarakat, bangunan moral dan intelektual, dalam penghayatan terhadap agama, kesadaran kebangsaan, dan derajat kemajuan prilaku dan kepribadian antara sesama masyarakat yang akan datang tergantung kepada remaja sekarang.

Para ahli mempunyai banyak pandangan yang berbeda satu sama lain untuk memberikan pengertian mengenai remaja. Hal ini di sebabkan kaum remaja masih menempati posisi yang samar atau belum jelas. Karna mereka masih tergolong anak-anak tetapi tidak termasuk golongan orang dewasa. Remaja merasa dirinya bukan anak-anak lagi akan tetapi mereka belum mampu memegang tanggung jawab seperti orang dewasa.

Anna Freud mendefinisikan " Masa remaja adalah suatu proses perkembangan meliputi perubahan-perubahan yang berhubungan dengan perkembangan psikoseksual, perubahan dalam hubungan dengan orang tua dan cita-cita mereka". 5

Masa remaja merupakan masa yang kritis sebab dalam masa remaja banyak dihadapkan dengan soal apakah ia dapat mengahadapi dan memecahkan masalah atau tidak. Dalam hal ini ketidak mampuan dalam menghadapi masalah dalam masa remaja akan menjadi orang dewasa yang tergantung.

\footnotetext{
${ }^{5}$ Singgih Gunarsa, Y. Singgih Gunarsa, Psikologi Perkembangan Anak dan Remaja, Jakarta, 1986, hal:202
} 
Pada masa kanak-kanak ada beberapa ciri yang menandainya sehingga menjadi jalas kedudukannya, yaitu ia belum dapat hidup mandiri, belum matang dalam segala segi, tubuh masi kecil, organ-organ belum dapat menjalankan fungsinya secara sempurna, kecerdasan, emosi dan hubungan sosial belum selesai pertumbuhannya. Hidupnya masih tergantung pada orang dewasa, belum dapat diberi tanggung jawab atas segala hal.

Dilihat dari tubuhnya, masa remaja kelihatan seperti orang dewasa, jasmaninya telah jelas berbentuk laki-laki/wanita, organ-organya telah dapat menjalankan fungsinya. Dan dari segi lain dia sebenarnya belum matang, segi emosi dan sosial masih memerlukan waktu untuk berkembang menjadi dewasa, kecerdasanya mengalami pertumbuhan mereka ingin berdiri sendiri akan tetapi belum mampu bertangguang jawab dalam soal ekonomi dan sosial.

Masa remaja adalah masa yang penuh kegoncangan, dimana jiwa mereka berada dalam peralihan atau diatas jembatan yang goyang yang menghubungkan masa kanak-kanak yang penuh ketergantungan dari masa dewasa yang matang dan berdiri sendiri.

Dengan demikian dari berbagai pandangan pengertian remaja tersebut, dapat disimpulkan sebagai pedoman dalam pembahasan selanjutnya bahwa remaja adalah beralihnya masa kanak-kanak menuju masa dewasa dengan rentang usia antara 14 tahun sampai 21 tahun.

\section{B. Faktor-faktor yang mempengaruhi terjadinya kenakalan remaja}

Kalau kita menaggapi banyaknya kasus yang terjadi pada anak remaja itu di karenakan tidak adanya control dari orang tua untuk mendidik anaknya. Maka dengan itu orang tua dianggap kurang mampu menanamkan keimanan pada anaknya yang mana dikarenakan adanya kesibukan masing-masing sampai-sampai mendidik anaknyapun terabaikan.

Maka dengan banyaknya bermunculan kasus tentang kenakalan yang dilakukan oleh anak-anak yang beru mulai meningkat/beranjak dewasa dikarenakan tidak adanya pengawasan dari orang tua tersebut dan lingkungannyapun kurang mendudkung itu dikatakan sebagai salah satu penyebabnya. Serta guru-gurupun ikut dianggap bertanggung jawab.

Maka dengan itu secara garis besar faktor yang mempengaruhi terjadinya kenakalan remaja bisah di golongkan menjadi tiga antara lain:

a) Faktor keluarga 
Keluarga adalah sebuah wadah dari permulaan pembentukan peribadi serta tumpuhan dasar fundamental bagi perkembangan dan pertumbuhan anak. Lingkungan keluarga secara potensial dapat membentuk peribadi anak menjadi hidup secara bertanggung jawab, apabila usaha pendidikan dalam keluarga itu gagal, akan terbentuk seorang anak yang lebih cenderung melakukan tindakan-tindakan yang bersifat kriminal, padahal dalam hadist sudah diatur.

b) Faktor sekolah

Sekolah adalah suatu lingkungan pendidikan yang secara garis besar masih bersifat formal. Anak remaja yang masih duduk dibanggku SLTP maupun SMU pada umumnya mereka menghabiskan waktu mereka selama tujuh jam disekolah setiap hari, jadi jangan heran bila lingkungan sekolah juga sangat berpengaruh terhadap perkembangan moral anak.

Kepala sekolah dan guru adalah pendidik, disamping melaksanakan tugas mengajar, yaitu mengembangkan kemampuan berpikir, serta melatih membinah dan mengembangkan kemampuan berpikir anak didiknya, serta mempunyai kepribadian dan budi pekerti yang baik dan membuat anak didik mempunyai sifat yang lebih dewasa.

Dr. Zakiah Daradjat mengatakan behwa yang menyebabkan kenakalan remaja diantaranya adalah kurang terlaksananya pendidikan moral dengan baik. ${ }^{6}$

Kerena kebanyakan guru sibuk dengan urusan pribadinya tanpa dapat memperhatikan perkembangan moral anak didiknya, anak hanya bisah diberi teori belaka sementara dalam perakteknya gurupun melanggar teori yang telah disampaikan pada anak didiknya. Padahal guru merupakan suri tauladan yang nomor dua setelah orang tua, makanya setiap sifat dan tingkah laku guru menjadi cerminan anak didiknya. Bila pendidikan kesusilaan dalam agama kurang dapat diterapkan disekolah maka akan berakibat buruk terhadap anak, sebab disekolah anak menghadapi berbagai macam

\footnotetext{
${ }^{6}$ Zakiah Drajat, Kesehatan Mental, Bulan Bintang, ( Bandung 1989 ) hlm.15-16
} 
bentuk teman bergaul. Dimana didalam pergaulan tersebut tidak seutuhnya membawa kebaikan bagi perkembangan anak.

c) Faktor masyarakat

Masyarakat adalah lingkungan yang terluas bagi remaja dan sekaligus paling banyak menawarkan pilihan. Pada lingkungan inilah remaja dihadapkan berbagai bentuk kenyataan yang ada dalam kehidupan masyarakat yang berbeda-beda, apalagi dasawarsa terakhir ini perkembangan moral kemajuan ilmu pengetahuan dan tehnologi berkembang dengan pesat, sehingga membawa perubahan-perubahan yang sangat berarti tetapi juga timbul masalah yang mengejutkan. Maka dalam situasi itulah yang menimbulkan melemahnya norma-norma dan nilai-nilai dalam masyarakat akibat perbuatan sosial. Akibatnya remaja terpengaruh dengan adanya yang terjadi dalam masyarakat yang mana kurang landasan agamanya, dan masyarakat yang acuh terhadap lingkungan yang ada disekitarnya.

Upaya penangulangan kenakalan remaja telah banyak dilakukan oleh perorangan atau kelompok secara bersam-sama untuk mendapat hasil yang dingginkan dengan itu pula dapat menjadikan remaja bisa atau dapat menerima keadaan dilingkungannya secara wajar.

Zakiah mempunya alternatif dalam menghadapi kenakalan remaja yang mana dalam bukunya yang berjudul tetang kesehatan mental sebagai berikut:

1 Pendikan agama .

Pendidikan agama harus dimulai dari rumah tangga, pada anak tersebut masih kecil tetapi yang paling terpenting adalah percaya kepada Tuhan. Serta dapat membiasakan atau mematuhi dan menjaga nilai-nilai dan kaidah-kaidah yang ditemukan didalam ajaran agama tersebut.

2 Orang tua harus mengerti dasar-dasar pendidikan. 
Pendidikan dan perlakuan yang diterima oleh anak sejak kecil merupakan sebab pokok dari kenakalan anak, maka orang tua harus mengetahui bentuk-bentuk dasar pengetahuan yang minimal tentang jiwa anak dan pokok pendidikan yang harus dilakukan dalam menghadapi bermacam-macam sifat anak.

3 Pengisian waktu luang dengan teratur.

Cara pengisian waktu luang kita jangan membiarkan anak mencari jalan sendiri. Terutama anak yang sedang menginjak remaja, karena pada masa ini anak banyak menhadapi perubahan yang bercam-macam dan banyak menemui problem pribadi. Bila tidak pandai mengisi waktu luang, mungkin akan tenggelam dalam memikirkan diri sendiri dan menjadi pelamun.

4 Membentuk markas-markas bimbingan dan penyuluhan.

Adanya markas-markas bimbinga dan penyeluruhan disetiap sekolah ini untuk menampung kesukaran anak-anak nakal.

5 Pengertian dan pegalaman ajaran agama.

Hal ini untuk dapat menghindarkan masyarakat dari kerendahan budi dan penyelewengan yang dengan sendirinya anak-anak juga akan tertolong.

6 Penyaringan buku-buku cerita, komik, Film-film dan sebagainya.

Sebab kenakalan anak tidak dapat kita pisahkan dari pendidikan dan perlakuan yang diterima oleh anak dari orang tua, sekolah dan masyarakat. ${ }^{7}$

Maka dengan itu wujud dan jenis kenakalan remaja tidak lagi bernilai kenakalan biasa, tetapi akan menjadi kekalan tindak keriminal yang dapat mengaggu atau meresahkan masyarakat, oleh sebab itu suatu kewajiban bersama dalam menaggulangi terjadinya kenakalan remaja, baik penaggulangan secara preventif maupun secara represif.

${ }^{7}$ Ibid. hlm. 121-125 
Serta dengan itu dari kedua penaggulangan baik yang bersifat preventif maupun represif itu dapat dijelaskan secara singkat:

a. Upaya penaggulangan secara prventif

Upaya penanggulangan secara preventif yaitu suatu usaha untuk menghindari kenakalan atau mencegah timbulnya kenakalan-kenakalan sebelum rencana kenakalan itu bisah atau setidaknya dapat memeprkecil jumlah kenalan remaja setiap harinya.

Agar dapat mewujudkan upaya penggulangan tersebut perlu dilakukan langkah-langkah yang tepat dalam melakukan upaya preventif tersebut antara lain:

1. Dalam lingkungan keluarga.

Lingkungan keluarga merupakan lingkungan pertama dan terakhir dalam membentuk peribadi anak, sehingga langkah yang dapat ditempuh dalam upayah preventif ini antara lain

a. Menciptaka lingkungan keluarga yang harmonis dengan menghindari percecokan antara istri dan suami serta kerabat yang lain.

b. Menjaga agar dalam keluarga jangan sampai terjadi perceraian, sehingga dalam keluarga tidak terjadi broken home

c. Orang tua hendaknya lebih banyak meluangkan wakru dirumah, sehingga mereka mempunyai waktu untuk memberi perhatian terhadap pendidikan anaknya.

d. Orang tua harus berupaya memahami kebutuhan anak-anaknya tidak bersikap yang berlebihan, sehingga anak tidak akan menjadi manja.

e. Menanamkan disiplin pada anaknya.

f. Orang tua tidak terlalu mengawasi dan mengatur setiap gerak gerik anak, sehingga kebebasan berdiri sendiri akan tertanam.

2. Dalam lingkungan sekolah

Langkah-langkah untuk melakukan upaya pencegahan dalam lingkungan sekolah: 
a. Guru hendaknya menyampaikan materi pelajaran tidak membosankan, dan jangan terlalu sulit sehingga motivasi belajar anak tidak menurun secara deraktis.

b. Guru harus memiliki disiplin yang tinggi terutama frekuensi kehadiran yang lebih teratur didalam hal mengajar.

c. Antar pihak sekolah dan orang tua secara teratur dapat mengadakan kerjasama dalam membentuk pertemuan untuk membicarakan masalah pendidikan dan prestasi siswa.

d. Pihak sekolah mengadakan operasi ketertiban secara kontinyu dalam waktu tertentu.

e. Adanya sarana dan prasarana yang memadai guna mendukung berlangsungnya proses belajar mengajar, sehingga siswa merasa kerasan disekolah.

3. Dalam lingkungan masyarakat.

Langkah-langkah pencegahan yang harus ditempuh masyakat antara lain:

a. Perlu adanya pengawasan atau kontrol dengan jalan menyeleksi masuknya unsur-unsur baru.

b. Perlu adanya pengawasan terhadap pengedaran buku-buku seperti komik, majalah ataupun pemasangan iklan-iklan yang dianggap perlu.

c. Menciptakan kondisi sosial yang sehat, sehingga akan mendukung perkembangan dan pertumbuhan anak.

d. Memberi kesempatan untuk berpartisipasi pada bentuk kegiatan yang lebih relavan dengan adanya kebutuhan anak muda zaman sekarang.

b. Upaya penanggulangan secara represif

1. Upaya penaggulangan secara represif seperti tertulis Yulia dan gunarsa adalah " suatu usaha atau tindakan untuk menindas dan menahan kenakalan remaja sesering mungkin atau menghalagi timbulnya peristiwa yang lebih kuat". 8

2. Upaya ini bisa diwujudkan dengan jalan memberi peringatan atau hukuman kepada remaja diliquent terhadap setiap pelangaran yang dilakuan setiap remaja. Bentuk

\footnotetext{
${ }^{8}$ Y. Singgih Gunarsa dan Singgih Gunarsa, Op. Cit. hlm 140
} 
hukuman tersebut bersifat psikologis yaitu mendidik dan menolong agar mereka menyadari akan perbuatannya dan tidak akan mengulangi kesalahannya.

3. Upaya penaggulangan secara represif dari lingkungan keluarga dapat ditempuh dengan jalan memdidik anak hidup disiplin terhadap peraturan yang berlaku dan bila dilanggar harus ditindak atau diberi hukuman sesuai dengan perbuatannya.

4. Dalam lingkungan masyarakat tindakan represif dapat ditempuh dalam memfungsikan peran masyarakat sebagai kontrol sosial yaitu dengan langkah-langkah sebagi berikut

1. Memberi nasehat secara langsung kepada anak yang bersangkutan agar anak tersebut meninggalkan kegiatannya yang tidak sesuai dengan seperangkat norma yang berlaku, yakni norma hukum, sosial, susila dan agama.

2. Membicarakan dengan orang tua anak yang bersangkutan dan dicarikan jalan keluar untuk anak tersebut.

3. Sebagai langkah terakhir masyarakat untuk lebih berani melaporkan kepada yang berwajib tentang adanya perbuatan dengan disertai bukti-bukti yang nyata, sehingga bukti tersebut dapat dijadikan dasar yang kuat bagi instansi yang berwenang didalam menyelesaikan kasus kenakalan remaja.

5. Dalam lingkungan sekolah tindakan represif dapat diambil sebagai langkah awal adalah dengan memberi teguran dan peringatan jika anak didik kita melakukan pelanggaran terhadap tata tertib di sekolah. Bentuk hukuman tersebut bisa berupa melarang bersekolah untuk sementara waktu. Hal ini dilakukan agar menjadi contoh bagi siswa lainya, sehingga dengan demikian mereka tidak mudah melakukan pelangaran atau tata tertib sekolah.

c. Upaya penanggulangan secara kuratif dan rehabilitasi

Tindakan kuratif dan rehabilitasi dalam mengatasi kenakalan remaja berarti usaha untuk memulihkan kembali (menolong) anak yang terlibat kenakalan agar kembali dalam perkembangan yang normal atau sesuai dengan aturan-aturan/norma-norma hukum yang berlaku. Sehingga pada 
diri siswa tumbuh kesadaran dan terhindar dari keputusasaan (frustasi). Penanggulangan ini dilakukan melalui pembinaan secara khusus maupun perorangan yang ahli dalam bidang ini.

\section{A.Kesimpulan}

Berdasarkan uraian yang telah penulis kemukakan di depan, maka penulis dapat simpulkan sebagai berikut:

1. Bahwa menurut bentuk/jenis kenakalan remaja pada umumnya termasuk bentuk/jenis kenakalan yang tergolong kenakalan ringan. Yakni jenis kenakalan yang tidak sampai melanggar hukum.

2. Bahwa yang menjadi penyebab terjadinya kenakalan remaja di pengaruhi oleh: Lingkungan keluarga yang kurang menerapkan disiplin terhadap anak-anaknya yang akhirnya menimbulkan sifat egois. Penyebab ini merupakan kemauan dari individu itu sendiri.

Lingkungan sekolah yang mana kenakalan tersebut timbul karna pengaruh dari temanteman.

Lingkungan masyarakat dimana anak melakukan hubungan sosialnya atau menghabiskan sebagian waktu luangnya. 
3. Upaya yang harusnya dilakukan dalam menanggulangi kenakalan remaja adalah dengan cara:

- Preventif (mencegah), yang diterapkan dengan memberi pendidikan agama kepada para siswa, mengadakan pembinaan melalui kegiatan ekstrakulikurer, dan meningkatkan efektifitas fungsi hubungan orang tua dan masyarakat.

- Represif (pencegahan), bertujuan untuk menahan dan menghambat kenakalan remaja sesering mungkin dan jangan sampai timbul peristiwa yang lebih lanjut. Dengan memberikan nasehat yang baik kepadanya, memberikan bimbingan dan pengarahan.

Daftar pustaka :

Singgih Gunarsa, Y. Singgih Gunarsa, Psikologi Perkembangan Anak dan Remaja, Jakarta, 1986 Zakiah Daradjat,Kesehatan Mental,CV Mas Agung,Jakarta,1989

Winarno Surakhmad, Psikologi Pemuda, Jenmars, Bandung, 1997

Nurdin Samauna, Pengarug Globalisasi Terhadap Moral Remaja Sebagai Sumberdaya Manusia Dalam PJPT II, no,36/XII/oktober 1994

TAP MPR RI NO.IV/MPR/1999, tentang GBHN, Sinar Grafindo, Jakarta, 1999,2000, 